\title{
MENGASUH ANAK DALAM PANDANGAN SAMIN
}

(Sekolah dalam Perspektif Sedulur Sikep Blora)

\author{
Sadiran \\ Sekolah Tinggi Agama Islam Ngawi \\ Email: $\underline{\text { sadiran@yahoo.co.id }}$
}

\begin{abstract}
This study uses a post-structural sociology approach i.e. ethno-methodology as a basis to attract normative behavior. Habitus Theory is used to analyze the habit of Sedulur Sikep's parent in nurturing their children, supported by the Bourdieu's theory of social distinction. Habitus theory is associated with behavior, language, culture, education and art in social and cultural daily life. While social distinction is used to see and understand how each parent of Samin take a position as a teacher. The first theory is to identify the main theories of habituation behavior conducted in childcare by parents of Samin, while the second theory is a supportive theory, in order to see the extent of the influence of parents on parenting. Child-rearing theory used Thomas Lickona's theory of parenting. The research data collection was using constructive phenomenological approach, which is to find the essential meaning of the Patterns of Child Care, which includes Samin's daily activities, rituals and traditions. Based on the data analysis, it is found that the parents' suspicions to formal education is the fear that their children will get negative influence from their mates that consequently ignore the messages of his ancestors. In addition, they afraid if their children will be difficult to receive advise because schools do not teach behaviors. Parenting is a parental obligation that should not be delegated to teachers at school, and to become parent as well as a teacher at once for their children is human nature so does not need to learn from others. Parents to their children put permissive and openness characters forward so that in time the parents are living reminder of how well the ancestral messages such as their way of life, way of thinking, and way to get along in daily life. However, the parents will still give example in the life of the children. The parenting system is integration between the outer (lahir) and inner (batin), while the method is close-distanced communication within the family, mligi (consistently) be given little by little since childhood. When their son made a mistake, they (sons) realize it by themselves. Intervention from outer parties is not yet needed because it is difficult to get space for interaction so that social change was not able to make influences.
\end{abstract}

\section{Keywords: Patterns of Child Care, Social Change, and Samin}

\section{PENDAHULUAN}

Setiap orang tua memiliki pola asuh yang unik; di mana mereka berkecenderungan agar anaknya menjadi "be special" dari pada "be average or normal". Pada tahun 1819 juga pernah ada lembaga pendidikan diberi nama dengan istilah sekolah desa. Sekolah tersebut pertama kali di cetuskan oleh pemerintah Belanda pada akhir abad 17. Pada saat itu 
Gubernur Jenderal Van der Capellen memerintahkan kepada aparatnya agar mengadakan penelitian terhadap masyarakat Jawa. Satu abad berikutnya penelitian tersebut dibicarakan kembali agar dilaksanakan jenis pendidikan yang berdasarkan pribumi murni, secara teratur dan disesuaikan dengan masyarakat desa yang dihubungkan erat pada pendidikan Islam yang sudah ada sebelumnya Berbeda dengan Van der Chijs dan beberapa pembantunya menilai bahwa tradisi didaktis pendidikan Islam terlalu jelek. Akibat penilaian itulah maka Menteri Kolonial menolak memberikan subsidi kepada sekolah sekolah Islam yang pada akhirnya hanya berhasil mengembangkan suatu sistem pendidikan yang sebenarnya tidak menguntungkan pengaruh dan kewibawaan pemerintah kolonial. Berdasarkan pertimbangan tersebut maka didirikan apa yang disebut sekolah desa, yaitu sebuah lembaga pendidikan sederhana yang memberikan jalan ke arah terwujudnya pendidikan "umum” (Saridjo, 1996).

Menurut Karel A. Steenbrink sikap seperti digambarkan di atas merupakan usaha anti Islam dari orang Belanda. Semenjak abad ke delapan belas sebenarnya pemerintah kolonial Belanda telah menyadari akan pentingnya peranan dan keberadaan sekolah-sekolah agama sebagai tempat pendidikan bagi anak-anak pribumi. Menyekolahkan kembali masyarakat merupakan gerakan bersama tidak sekedar mengajar.

Samin adalah salah satu sub etnis di Jawa Tengah yang keberadaanya sangat diperhatikan oleh pemerintah Daerah Kabupaten Blora. salah satu contoh perhatian pemerintah Daerah Tingkat II Kabupaten Blora mendirikan bangunan besar bertingkat di Depan Alun-alun kota Blora. bangunan megah tersebut diberi nama gedung Surosentiko. Nama Surosentiko adalah kepanjangan nama dari Ki Samin. Sosok tokoh desa yang memiliki karisma pada zaman penjajah. Di samping itu, masih ada lagi sebuah baliho berukuran besar yang menancap di sebelah alun-alun kota Blora, berupa sebuah foto Ki Samin Surosentiko dan kawan-kawanya berjumlah 5 (lima) orang tokoh Samin.

"Kearifan lokal Sedulur Sikep Perlu di jaga dan Lestarikan".Bunyi tulisan yang ada pada papan besar Ki Samin 5 (lima) saudara, yaitu: $\mathrm{Ki}$ Samin Surosentiko, Surokidin, Lasiban, Godek, dan Lasiyo. Bunyi tulisan yang sangat syarat dengan ajakan ini bahkan terucap dari seseorang yang bukan pengikut $\mathrm{Ki}$ Samin Surosentiko (Int. Lasiyo, 8 Januari 2016). Kearifan lokal Sedulur Sikep merupakan bagian dari masyarakat Blora.

Pertanyaan besar nya adalah mengapa keberadaan warga Sedulur Sikep masih eksis sampai sekarang ?. Pamugi 
Prawiro Wijoyo salah satu tokoh Samin di Blimbing mengatakan wong sing tumindake becik akire salin sandangan iso awor karo wong apik ( orang yang berbudi pekerti yang baik jika meninggal dunia akan bersama dengan orang baik).

Fasafah jawa kesandung lemah rata, ketatap ing awang awang mempunyai maksud bahwa manusia jangan sampai bersikap sombong, berperilaku keterlaluan, serta suka menyakiti perasaan orang lain secara sengaja (Gesta Bayuadhy, 2015: 189). Kesandung lemah rata sama artinya dengan ketatap ing awang awang. Orang yang merasa dan terlihat aman, baik atau bahkan tidak mungkin terkena kejadian tak terduga ternyata bisa mengalami sesuatu yang tragis. Peristiwa menyedihkan tersebut membuat orang-orang bertanya-tanya gek salahe apa (apa kesalahan atau dosanya). Ajaran Ki Samin Surosentiko dijelaskan, jika manusia perilakunya baik ketika hidupnya, maka dia akan ikut manusia lagi ketika sudah mati, demikian juga sebaliknya kalau amalnya jelek tidak bisa kumpul dengan manusia. Mereka akan menempel pada hewan, batu, pohon besar, dan lain-lain, sehingga tidak ada pengaruhnya di do'akan oleh keluarga yang masih hidup atau tidak, seperti umumnya acara slametan yang dilakukan oleh orang Jawa. Tradisi Sedulur Sikep yang dikembangkan semata-mata hanya laku urip (perjalanan hidup), slamet gumantung ono awake dewe (selamat tidaknya seseorang tergantung pada perbuatan dirinya sendiri ketika masih hidup di dunia). Seperti halnya ketika orangtua melahirkan anak, menurut ajaran Ki Samin bayi lahir niku nggowo sedulur telu (bayi lahir diikuti oleh saudara berjumlah tiga), yaitu kakang kawah adi ari-ari. Bayi yang baru lahir menurut $\mathrm{Ki}$ Samin, tri tunggal nggih niku kakang kawah, bayi lan adi ari-ari (cairan yang pecah mengawali lahirnya seorang bayi, kedua plasenta dan ketiga bayi itu sendiri).

Menurut penuturan para orang tua Sedulur Sikep (Int. Samidi, Juli 2016), diyakini, bahwa bakale menungso niku wonten papat yoiku pedes, asin, kecut, lan pahit (bibit manusia berasal dari 4 macam rasa, yaitu: pedas, asin, asam, pahit) . Mereka tidak dibenarkan mengeluh ketika sakit dan senang ketika mendapat banyak rizki. Semua harus disikapi bahwa itu hanya semata-mata merupakan proses dalam kehidupan ini, artinya tidak perlu dianggap keberuntungan ketika mendapat kesenangan dengan mengadakan syukuran dan menganggap musibah dikala menerima sesuatu yang tidak menyenangkan. Bagi ajaran Samin persoalan sulit dan lancar/mudah semata-mata hanya merupakan kelengkapan hidup. Hal ini diberikan kepada semua manusia untuk menguji kesabaran dan keuletan di dalam bekerja untuk menghidupi keluarganya. 


\section{Teori Habitus}

Sumbangan khas Bourdieu secara umum terdapat dalam empat konsep berikut: habitus, kapital (modal), arena, dan distinction. Pertama konsep habitus dapat mengatasi dikotomi antara individu dan masyarakat, antara agensi dan struktur sosial dan antara kebebasan dan determinisme.

Bourdieu lebih cenderung menentukan perilaku sosial sebagai penentu dengan pendekatan yang berbeda. Bagi Bourdieu, posisi pelaku juga memiliki keterkaitan dengan ruang. Artinya, seseorang harus menghadapi struktur objektif. Struktur objektif adalah kondisi konkret dimana seseorang harus berpikir secara realistis cara menghadapinya Dalam hal ini, Bourdieu realistis, artinya dia memperhitungkan tindakan yang tidak bisa dilepaskan dari kepemilikan kapital-kapital serta arena yang dihadapinya.

Teori habituasi digunakan karena kedetailannya dalam menjelaskan fungsi dan proses pelibatan budaya dan tradisi dalam representasi perilaku sosial. Praktek habituasi dinilai mengarah pada dimensi mikro karena kedekatan basis setting penelitiannya yang banyak terkait dengan perilaku, bahasa, budaya, dan seni dalam kehidupan sosial dan budaya keseharian komunitas atau institusi. Sebab itulah, teori habituasi menjadi yang penting. Secara psikis habitus mewujud berbentuk nilai-nilai yang dipraktekkan dan moral yang diinternalisasikan, seperti etika dan norma pada orang tua yang tidak mengemuka dalam kesadaran, tetapi mengatur perilaku keseharian.

\section{Teori Distinksi Sosial}

Teori ini digunakan untuk melihat dan memahami bagaimana setiap orang tua Samin mengambil posisi sebagai guru. Dengan peran sebagai guru maka akan terbangun identitas dan status sosial yang mewujud sebagai perilaku yang dikembangkan sebagai figur. Distinksi dapat digunakan untuk melihat bagaimana komunitas Samin secara keseluruhan membentuk tradisi tersendiri yang membedakannya dengan masyarakat non-Samin. Dalam skala makro, habitus merupakan pengondisian yang masih terkait erat dengan syarat-syarat kebendaan. Habitus menghasilkan serangkaian sistem disposisi yang tahan waktu sehingga dapat diwariskan baik secara biologis maupun sosial sebagai struktur yang dibentuk, yang akhirnya menciptakan pola sikap dan perilaku sebuah masyarakat. Bourdieu menuturkan habitus dapat menjadi penggerak sekaligus pengatur praktek hidup dan representasi di mana individu dalam sebuah masyarakat dapat menyelaraskan secara mekanik.

\section{Thomas Lickona}

Menurut Lichona ada banyak cara 
lain yang bisa kita lakukan moral knowing, moral feeling, and moral behavior. Good character consists of knowing the good, desiring the good, and doing the good. Menurut Lickona ada tiga komponen utama dalam pengasuhan, yaitu: moral knowing, moral feeling, moral action. Moral feeling Tanggung jawab yang penting lainya adalah melakukan pekerjaan yang terbaik disekolah dan memanfaatkan secara maksimal pendidikan mereka (Lickona, 2013: 73). Penulis Life's Greater Lesson, mengatakan bahwa tugas kita sebagai orang tua adalah untuk menggali potensi terbaik dalam diri anak-anak kita.

4. Teori Pola Asuh Garbarino dan Ben

Pola asuh menurut Garbarino dan Ben sebagaimana dikutip oleh Kosim, mengatakan bahwa pengasuhan (parenting) adalah suatu perilaku yang pada dasarnya mempunyai kata kunci, yaitu: kehangatan, sensitif, penuh penerimaan, bersifat resiprokal, ada pengertian, dan respons yang tepat pada kebutuhan anak (Nanang Kosim, 280).

Ben mengatakan bahwa dalam pengasuhan tipe ini keterlibatan seorang ayah ada dalam tiga bentuk, yaitu: (1) Engagement atau interaction, yaitu interaksi satu-satu dengan seorang anak. (2) Accessibility adalah bentuk keterlibatan yang lebih rendah, yaitu ayah sangat dekat dengan anak tetapi tidak mengadakan interaksi langsung dengan anak. Dalam hal keterlibatan ini ayah selalu memperhatikan dan mengharapkan agar kelak anak-anaknya dapat menjadi dambaan orang tua. (3) Responsibility adalah bentuk keterlibatan yang paling intens, karena melibatkan perencanaan, pengasuhan, pengambilan keputusan, dan pengorganisasian.

Orang tua warga Samin mengatakan bahwa keluarga adalah guru yang mengajarkan pengalaman bukan pengetahuan. Belajar di rumah bersama kedua orang tua akan mudah dilakukan dan mudah diawasi karena keterlibatan keduanya dapat terjadi sepanjang hari tanpa pembatasan ruang.

Tulisan Dedi Supriadi tentang Pendidikan Nilai mengatakan bahwa sebuah Megatrend, menjadi titik balik yang menempatkan isu-isu tentang nilai sebagai fokus perhatian adalah populernya kecerdasan emosional. Orang juga rindu untuk kembali melihat sebuah titik dalam diri manusia yang oleh Jean Paul Sartre disebut "God spot" sebuah ruang yang berisi keyakinan. Inti persoalanya adalah nilai, yakni tema-tema sentral makna kehidupan, didalamnya menyangkut dimensi-dimensi afektif dan nilai (Mulyana Rahmat, 2004)

Nilai dapat diajarkan melalui proses pendidikan. Sebenarnya keraguan dari para pakar pendidikan tentang dapat tidaknya nilai diajarkan. Kajian logika, etika dan 
estetika

\section{A. Sekolah Samin}

Dalam memaknai kata sekolah menurut Samin tidak seperti umumnya orang mengatakan bahwa sekolah itu ada tingkatan awal $(\mathrm{KB})$ atau perguruan Tinggi (PT).

Ketika pemakalah bertanya mengapa anak anak tidak sekolah. Mereka pada umumnya menjawab "anak kulo pun sekolah awit cilik nggih niku sekolah toto coro nyambut gawe sing mempeng lan tumindak becik karo sak podo-podo ( ketika di Tanya mengapa anak anak tidak bersekolah mereka (orangtua) menjawab bahwa anaknya sudah belajar sejak kecil yaitu belajar bekerja dan berbuat baik).

1. Fase-Fase Pola pengasuhan Anak Samin

Dalam Kamus Besar Bahasa Indonesia, pengasuhan berasal dari kata "asuh" yang artinya proses (Departemen Pendidikan dan Kebudayaan, 1990: 54). James, mengatakan bahwa pengasuhan mempunyai pengertian sosialisasi (James Danandjaja). Kata "mengasuh" lebih menekankan pada proses asah (berulang-ulang tanpa henti), tanpa batas waktu, dengan penuh kasih-sayang di antara keduanya, sampai pada tingkat bagaimana memberi makanan, membelikan pakaian melindungi dari gangguan baik dari dalam maupun dari luar. Pengasuhan bisa juga diartikan
al-Hadhanah (pengasuhan) yang berarti mendidik dan menjaga anak (Al-'Akk, 2006: 87). Kata al-Hadhanah adalah musytaq (turunan, derivasi) dari kata al-hadhnu. Bahwa seorang ibu lebih diprioritaskan dalam pengasuhan anak-anaknya daripada seorang ayah. Pola pengasuhan anak sedulur Sikep di bedakan menjadi 5 (lima) fase, sebagaiaman dijelaskan dibawah ini :

a. Anak Dalam Kandungan

Ajaran yang dibawa oleh Ki Samin Surosentiko dijelaskan bahwa setelah anak perempuan menyatakan pilihan untuk berkeluarga, dalam kemudian melakukan persetubuhan dengan anak laki-laki yang sudah lama Suwito dirumahnya, maka orangtuanya mengadakan upacara seksenan dengan mengundang tetangganya. Mereka bersuami istri kemudian mengandung anak, maka diadakan brokohan tukule wiji Adam. Acara ini dilakukan pada masa usia kandungan istrinya menginjak usia 4 (empat) bulan. Pengasuhan anak didalam kandungan sudah dimulai pada saat usia kandungan memasuki 4 bulan, yaitu mulai meninggalkan pantangan-pantangan, seperti tidak boleh membuang makanan, menyakiti binatang dan lain-lain. Tujuan dari peristiwa tersebut biar kelak anaknya lahir tidak cacat.

Ketika usia kandungan menginjak 7 (tujuh) bulan ada acara brokohan lagi yang namnya rujak-an (suami istri makan rujak). 
Orang Jawa mengatakan "mitoni" (tujuh bulan). Atau Brojolan, dengan memecah kelapa muda yang diberi gambar tokoh wayang yaitu Janaka dan Srikandi, kalau hasil pecahan kelapa tepat tengah dan lurus diharapkan akan lahir anak laki-laki dan kalau tidak lurus (sisip) berarti nantinya akan lahir bayi perempuan. Ketika kandungan sudah berumur 9 (sembilan bulan) orangtua menyediakan kuali kecil beserta tutupnya sebagai persiapan menunggu kelahiran anaknya.

b. Masa Kelahiran Anak

Menjelang kelahiran seorang anak, para orangtua Samin pada umumnya mempunyai kepercayaan bahwa ada saudara yang mengiringi pada saat bayi lahir, sedulur tunggal dino yaitu"kakang kawah adi ari-ari”. Kawah berupa cairan yang pecah dan keluar mendahului kelahiran bayi sedangkan ari-ari (plasenta) adalah merupakan kehidupan seorang bayi ketika masih di dalam kandungan. Kebiasaan umum orang tua Sedulur Sikep juga memberikan sebuah pangaran pada bayinya, kemudian setelah pangaran dipersiapkan dan baru mengumumkanya sebagaimana layaknya masyarakat Jawa dilingkungan wilayah yang bersangkutan (Int. Kemi, 8 Januari 2017).

Sebagaimana dijelaskan pada Bab III bahwa keluarga Sedulur Sikep agama mereka bukan Islam dan menganut aliran kepercayaan (PKT), maka bagi anak yang baru lahir tidak di bacakan adzan seperti umumnya orang Islam. Jika dilihat dari sisi perbedaanya dengan tradisi Jawa terletak pada lima hari pertama. Tradisi Samin setelah melahirkan para tetangga ramai-ramai berkumpul selama 5 (lima) hari penuh. Mereka meninggalkan. pekerjaan disawah dengan suka rela selama sepasar (lima hari).

Penuturan bah Lamijan, kerjo boten wonten telase pak, menawi niki paling suwe gangsal dinten, idep-edep leren kajenge menep (kerja tidak ada habisnya, kalau acara kelahiran paling lama lima hari selesai, supaya ada keseimbangan, wawancara dilakukan di rumah bah Jumini yang anaknya sedang melahirkan anak yang ke-dua, pada bulan Januari 2017

Pada umumnya mereka saling berdatangan dan saling membawa sandang pangan (bahan makanan pokok) secara gotong royong untuk membantu saudaranya dengan suka rela serta penuh keikhlasan, sandang-pangan tersebut tersebut diberikan semata-mata dengan tujuan untuk meringankan beban Saudaranya yang baru saja melahirkan. Pada umumnya semua warga Sedulur Sikep ketika selesai berbincang-bincang tentang apa saja yang di kerjakan di sawah mereka pada tidak seperti orang Jawa meninggalkan tempat dan pulang membawa oleh-oleh (angsul-angsulan), namun mereka berpamitan tanpa 
mendapatkan makanan sedikititpun. Tradisi ini umum bagi keluarga Samin. Ketika ditanya jawaban mereka ikhlas membantu dan murni tulus tidak mengharapkan apapun sebelum dan sesudahnya. Bantuan yang mereka berikan pada umumnya murni penuh dengan keikhlasan semata-mata hanya untuk membantu dan hanya sebatas untuk tambah seduluran (gotong royong sesama saudara).

Ketika hari kelima (sepasaran) semua tetangga berkumpul untuk menghadiri acara brokohan, sambil memberi pangaran bagi anaknya, agar kelak bayi yang baru lahir tersebut diberi umur panjang dan sehat jasmani maupun rohani. Acara tersebut cukup meriah karena semua keluarga sedulur Sikep bersama-sama datang dan gotong-royong memberikan bantuan berupa sandang pangan.

Selama peneliti bersama mereka tidak menemukan para warga sedulur Sikep yang cacat fisik. Keadaan tersebut yang berbeda dengan masyarakat non-Samin, ketika peneliti bertanya kepada warga Samin mengatakan "tiyang niku nek sing dipadang barang sae, pikiran sae sasambetan kalih tonggo sae nggih turune sae (orang itu kalau makan dari makanan yang baik/halal, pikiran baik dan bertetangga juga baik maka akan mempunyai keturunan yang baik juga).
Menawi wong tuwo lampahane becik, boten nyacat sak padane gesang, nggih boten nompo akibate ( jika orang tua berperilaku baik terhadap sesamanya maka tidak akan menerima akibat yang tidak diharapkan).

Ucapan Samin tersebut disampaikan dengan ungkapan yang mempunyai makna filosofi, bahwa apa yang diterima itu pada hakekatnya merupakan hasil tanamannya sendiri, apa yang dikerjakan orangtua terhadap orang lain, akan di terima sendiri (nandur bakale ngunduh). Gotong-royong yang sudah menjadi tradisi Samin perlu mendapatkan apresiasi sebab ketika saudaranya mempunyai keperluan/hajat maka kebutuhannya sendiri harus dikalahkan agar sedapat mungkin bisa membantu sedulur yang baru memerlukan bantuan dalam mencukupi hajatnya. Perilaku semisal ini sangat jarang dijumpai pada masyarakat non-Samin. Pada umumnya seseorang yang membantu pasti terikat dengan saudara, jika bukan saudara juga tidak dilakukan.

Pola asuh pada tataran ini sangat mengesan pada anak-anak Samin, sehingga ketika generasi tua sudah tiada mereka secara otomatis bisa meneruskan perilaku yang dikerjakan oleh orangtuanya.

c. Pengasuhan Pada Masa Bayi

Anak yang baru lahir wajib mendapat kasih sayang dan belahan kasih dari seorang ibu sehingga mereka semua 
selalu mendapatkan ASI dari ibunya sendiri. Pemahaman orang Samin tersebut menjadi perekat antara ibu dan anak yang baru dilahirkan. Karena anak adalah bagian dari hidupnya maka orangtua Samin tidak ada yang membeli susu kaleng/instan yang dijual umum di toko maupun di tempat lainya. Anak yang dilahirkan selalu diberi ASI langsung dari "Yong'e" (ibunya) sendiri.

Pola pengasuhan anak dimasa bayi dan masih dalam ayunan orang tuanya, bayi selalu mendapatkan kehangatan kasih sayang langsung diasuh dengan penuh kasih sayang tanpa menggunakan jasa baby suster. Bukan karena sang ibu tidak punya pekerjaan atau jabatan yang tinggi, namun memang kodrat ibu melahirkan dan menyusui, membesarkanya dengan penuh pengabdian, maka kemana pun orangtua bekerja bayi selalu digendong (diasuh) oleh ibunya sambil membawa pisau atau gunting sebagai salah satu alat untuk membela diri, sewaktu ada musibah. Pola asuh yang di lakukan ibu adalah ketika pengasuhanya baik maka akan menjadi anak yang baik pula dan kelak ketika sudah besar akan mampu menyenangkan hati orangtuanya. Maka ibu selalu membimbing kejalan yang diajarkan oleh Ki Samin yaitu agar selalu mengikuti pesan-pesan orangtuanya.

Ibu yang masih menggendong bayinya tidak mendapatkan pekerjaan di sawah (Int. Parmi, 7 Juli 2016). Ayah sebagai penanggung jawab ekonomi selalu menyempatkan diri bertemu dengan anaknya yang masih bayi walaupun dalam keadaan sibuk. Kebiasaan tersebut membuat keluarga menjadi lebih harmonis dan saling menguatkan diantara suami istri. Orang Samin juga bahagia bersama anaknya walaupun ekonomi mereka tergolong kekurangan. Pola asuh yang diberikan orangtua sewaktu anaknya masih bayi mempunyai sentuan yang sangat baik kelak dimasa-masa mendatang.

d. Pengasuhan Pada Masa Usia Sekolah

Anak-anak usia sekolah, generasi Samin dibebaskan tanpa dihalang-halangi atau didorong agar sekolah atau tidak sekolah (Int. salim. 6 Juli 2016). Anak bebas sekolah dimanapun yang dipilih dan tidak di persoalkan apabila tidak mau sekolah formal, tergantung anak bagaimana mau atau tidaknya untuk pergi ke sekolah. Jika mau sekolah diantar dan didaftarkan oleh ayahnya. Berhubung mereka tidak mempunyai akte kelahiran atau surat kelahiran dari desa, maka mereka mengatakan kepada pihak sekolah boleh tidaknya anaknya sekolah di lembaga formal itu.

Pada umumnya kepala sekolah SD tidak keberatan menerima siswa dari keluarga sedulur Sikep tersebut walaupun tidak membawa akte kelahiran namun 
tetap diperbolehkan sekolah di lembaga pendidikan Negeri walaupun tidak mempunyai akte kelahiran. Kalau putus di tengah jalan sehingga tidak sampai lulus, dalam hal ini orangtua juga tidak menasehati dan langsung menerimanya (legowo), tidak marah dan juga tidak menyuruh agar menunggu sampai lulus sampai kelas VI (enam). Sewaktu peneliti bertanya kepada orang tuanya ketika melihat anak-anak usia kelas II (dua) dan kelas III (tiga) SD tidak sekolah, para orangtua itu pada umumnya menjawab dengan singkat la pripun sing nglakoni mboten purun (bagaimana lagi yang bersangkutan tidak mau sekolah) (Int. Kasbi). Samin pantang memaksakan kehendak seorang anak. Apapun keputusan anak selalu diberi kelonggaran oleh orangtuanya. Selama keinginan anak tidak menyimpang maka tidak dihalang-halangi.

Pada usia SMP dan SMA pada umumnya sudah suwito dirumah calon mertuanya. Samin tanpa batas waktu di saat melakukan suwito dirumah calon mertuanya, mereka pada umumnya belum mempunyai target harus berapa lama bekerja sebagai awal berkeluarga. Bagi anak se-usia SMP tentunya belum memikirkan apa-apa kecuali hanya bekerja. Ketika di rumah dan menginap di lokasi penelitian tidak ditemukan anak usia SMP yang masih ikut orangtuanya sendiri. Mereka pada umumnya sudah suwito bekerja dirumah calon mertuanya dengan harapan ingin memperistri anaknya.

Penemuan di lapangan ternyata mereka pada umumnya bukan keinginan murni dari anak, ternyata atas masukan dan saran dari kedua orangtuanya, agar suwito terlebih dahulu di rumah sedulur sikep yang didalamnya mempunyai anak perempuan yang belum berkeluarga. Hubungan kekeluargaan diantara mereka sangat dekat, sehingga orangtua ikut campur dalam urusan perkawinan anak laki-lakinya.

e. Pengasuhan Masa Remaja

Pada masa remaja (Samin Birahi) khususnya anak perempuan selalu menerima saran dan masukan dari orang tuanya, terutama ketika pada masa memasuki usia berkeluarga. Para perempuan tidak ada yang menunggu jodoh, sebab pada umumnya anak belum birahi sudah ada yang suwito dirumahnya, anak perempuan selalu mengikuti saran dan pesan ibunya (Yong'e). Anak-anak muda tidak ada yang merantau keluar kota apalagi menjadi TKW, bagi keluarga sedulur Sikep pergi kemanapun sama saja dirumah yaitu mencari makan. Sementara di rumah kalau mau bekerja dengan giat di sawah juga akan dapat rizki untuk dimakan sekeluarga juga cukup.

Jika remaja laki-laki menginginkan sesuatu harus rela berkorban dan berjuang sekuat tenaga tanpa mengharapkan 
imbalan materi, sebagai langkah awal menuju keluarga tentu perlu waktu untuk saling mengerti diantara keduanya, diharapkan apa yang dikerjakan mempunyai nilai manfaat dan berdaya guna, demi masa depanya. Sikap suwito bagi seorang remaja tidak mudah karena harus hidup dilingkungan baru bersama orang yang belum dikenalnya. suwito wajib dilakukan bagi remaja yang menginginkan seorang wanita sebagai calon pendampingnya.

\section{f. Pengasuhan Masa Dewasa}

Mereka berkeluarga tidak serta merta dilepas oleh orang tuanya, namun masih dibantu bahkan diberi bekal berupa sawah dan rumah sebagai bekal proses memulai hidup berkeluarga (keluarga baru). Anak-anak mereka selalu dibimbing dan dipantau kebutuhan sehari-harinya sampai bisa mandiri dan bisa mencari nafkah untuk menghidupi keluarganya.

Dalam kondisi umum, anak adalah buah hati belahan cinta, tempat bergantung dihari kedua orang tuanya kelak di usia tua, sebagai generasi penerus yang dicita-citakan oleh kedua orang tuanya. Anak baik laki-laki maupun perempuan adalah sebagai buah hati keluarga dengan iringan doa dan harapan kelak menjadi pemimpin atau imam bagi orang-orang disekitarnya. Bagi Samin sedikit berbeda sebab anak merupakan amanat untuk dididik dan diasuh, dibesarkan sesuai dengan tujuan penciptaan manusia, yaitu mengabdi kepada kedua orangtuanya.

Menginjak dewasa dan mampu mengurus diri sendiri maka anak tidak boleh bermain dengan tetangga yang bukan menganut ajaran Samin (Int. Gemi, Januari 2017). Hal ini mempunyai tujuan agar anak tetap dalam suasana yang homogen, utuh dan utun selalu bersikap yang lugu dan berlaku jujur supaya mengikuti pesan dan nasehat dari kedua orangtuanya. Harapan orangtua bagi sedulur Sikep dengan demikian anak-anak dari generasi Ki Samin ini siap mematuhi pesan-pesan dari orangtuanya, pada umumnya Samin tidak suka berkumpul dengan tetangga. Hal ini dikarenakan sejak kecil anak-anak sudah dibimbing dan selalu dinasehati oleh kedua orangtuanya sendiri, seperti yang disampaikan oleh orang samian "tidak ada gunanya bermain atau umum disebut dolan dengan tetangga".

Menurut tradisi Samin batas usia anak berkeluarga tidak ada. Sejauh sudah dipinang oleh seorang jejaka orangtua hanya menerima tanpa ada pertimbangan matang, khususnya masalah usia, sehingga banyak anak-anak Sedulur Sikep yang sudah berkeluarga padahal mereka dalam usia masih tergolong anak-anak (isih dolan). Pada saat peneliti bertanya kepada para orangtua, mereka menjawab la pripun pun dikarepno (bagaimana lagi sudah 
diinginkan biar menunggu anak laki-laki beberapa tahun).

Temuan pola pengasuhan samin berupa, contoh gotong royong dan tindakan nyata berupa pengorbanan materi menunda keperluan pribadi untuk kebutuhan orang lain disamping imateri yaitu berupa pengorbanan untuk mendapatkan sesuatu yang diinginkan, ditempuh dengan usaha, giat bekerja, tidak berhenti sebelum berhasil, tanpa batas waktu sampai tujuanya terlaksana wujudnya suwito.

Setelah beberapa lama menjalin keluarga maka diharapkan kehadiran seorang anak agar dapat hidup normal seperti masyarakat lain pada umumnya, menurut mereka sempurnanya seorang yang berkeluarga ketika kehadiran seorang anak. Anak yang baru mengandung orangtua selalu memberikan nasehat-nasehat demi keselamatan calon bayinya. Pantangan-pantangan yang dilakukan oleh anak yang baru mengandung bayi dari kalangan warga Samin sama seperti pantangan yang dilakukan oleh orang Jawa. kelahiran anak selalu di tunggu-tunggu oleh semua keluarga baik orangtua maupun para tetangganya. Apa bila bayi sudah lahir keunikan orang Samin adalah orang-orang berkumpul selama 5 (lima) hari penuh sampai diselenggarakanya acara "sepasaran"(hari dimana anak diberi nama) sebagaimana dijelaskan didepan. Memberi nama anak masih dihubungkan dengan hari kelahiranyal agar mudah mengingat-ingatnya. Pola pengasuhan anak ketika masih bayi hampir sama seperti orang Jawa hanya terletak pada praktek. Pola pengasuhan anak bagi orang Samin selalu muncul dalam ucapan, saran masukan dan suritauladan yang dipraktekan langsung oleh kedua orangtuanya. Model pendidikan ini yang sedikit membedakan dengan masyarakat non-Samin, yang masih miskin suritauladan dari kedua orangtuanya sendiri.

Hubungan keluarga antara Mak'e lan Yong'e ( ayah dan ibu) bagi Warga Samin sangat terjaga dan antara satu dengan lainya saling menyayangi, menghormati dan menghargai, sehingga apa bila menyebut istrinya dengan ucapan-ucapan yang baik. Istri itu adalah "batur tunggal bantal (istri adalah saudara satu guling) (Int. Sariban, 4 Juli 2016). Sementara kalau menyebut garwo (istri) mereka mengatakan, garwo niku tuhan” (istri yang sebenarnya adalah Tuhan). Pemaknaan sebagaimana disebutkan di atas semata-mata hanya untuk memudahkan dalam berkomunikasi, karena mereka mempunyai pandangan yang sedikit berbeda dengan umumnya orang Jawa, misalnya kalau istri dikatakan Sedulur Tunggal Bantal secara logika memang 
benar karena mereka memaknai istri hanya dimaknai ketika tidur bukan dalam pengertian secara umum.

Masyarakat umum menyebut istri dengan istilah Garwo (Jawa). Hal tersebut mengingatkan bahwa seseorang yang sudah bersuami istri tidak bisa lepas dengan keinginan masing-masing. Mereka harus bersatu dalam merencanakan sesuatu yang terkait dengan kebutuhan sehari-hari. Sempurnanya hidup apabila yang satu dengan yang lainya itu bersatu dalam satu tujuan. Orang yang tidak mempunyai istri berbeda yaitu ketika masih hidup sendiri, keinginan bisa berbeda karena tidak ada orang lain yang mendampinginya. artinya sigarane nyowo, bisa diartikan tidak akan bisa kalau tidak bersatu menurut pemahaman orang Samin pengertian Garwo itu bukan istri. Tetapi garwo itu artinya tuhan. Sementara pemaknaan Garwo menurut orang Samin mempunyai pengertian bahwa garwo itu yang dapat memberi kehidupan yang sebenarnya, yaitu tuhan, menyatunya manusia dengan tuhan namanya bersatunya antara makhluk dengan sang kolik, maka disebut dengan istilah Garwo. Mengingat Garwo adalah tuhan, maka jika ingin dekat dengan Garwo hendaknya menjauhi kepentingan-kepentingan dunia. Sebagaimana yang terjadi pada warga Samin yang mengatakan bahwa jika ingin dekat dengan tuhan hendaknya menjauhi dunia, sebab kalau dekat dengan dunia adoh weweh (tidak suka memberi bantuan kepada orang lain) (Int. Karmidi, 10 Juli 2017). Orang yang bakil tidak akan ketemu dengan tuhan. Pemahaman Samin tentang Tuhan ada dan dekat denganNya ketika seseorang menjauhi urusan-urusan dunia (Int. Pramugi Prawiro Wijoyo, Juli 2017).

\section{a.Nilai Anak}

Di dalam kamus Besar Bahasa Indonesia, nilai artinya harga atau sifat yang penting dan berguna bagi kemanusiaan (Departemen Pendidikan dan Kebudayaan, 1990: 615). Anak merupakan subjek utama hak atas pendidikan. Anak bagi Samin merupakan titipan Tuhan yang tidak ternilai harganya. Nilai sebagai pola keyakinan yang pantas dan benar bagi diri kita dan bagi orang lain dalam sebuah lingkungan kebudayaan tertentu. Apabila diimplementasikan dalam nilai anak, maka yang dimaksud nilai adalah sesuatu yang diinginkan oleh orangtua khususnya warga Samin menyebut dengan istilah jawa yaitu mak'e lan yonge (ayah dan ibu) agar anak-anaknya sedapat mungkin berlaku jujur dengan siapapun dan bekerja keras demi masa depan keluarganya.

1. Pengasuhan Anak dalam Tradisi Samin

Sebagaimana di jelaskan diatas bahwa menurut Samin anak laki-laki dan perempuan dalam pengakuannya berbeda Anak niku ngenake (anak [perempuan] 
menawi anak lanang niku turun (nurunke wiji) (Int. Wakini, 6 Januari 2016). (dalam ajaran Samin, kalau anak perempuan itu melahirkan sedangkan kalau anak laki-laki itu menurunkan), anak perempuan itu melahirkan artinya hanya sebatas mengembangbiakan keturunan. Maka tanpa anak laki-laki tidak terjadi proses perkembangan-biakan itu. Sedangkan anak laki-laki itu akan menurunkan keturunan, maksudnya seseorang yang melahirkan anak laki-laki itu artinya turun dari ayahnya, adapun seseorang yang melahirkan anak perempuan itu hanya bisa seperti ibunya (Int. Salim, 8 Juli 2016).

Berdasarkan tradisi Jawa yang masih dijalankan oleh komuniutas Samin, baik warga Samin yang berdomisili di Tambak Balong maupun di wilayah lain di Kabupaten Blora, persoalan keturunan itu penting dan perlu di teliti ulang dengan penuh kehati-hatian. Misalnya anak perempuan ini tidak bisa dianggap turun dari orang tuanya (ayah), mereka hanya cukup disebut dengan anak (ngenake), karena itu tidak bisa melanjutkan ilmu dari orang tuanya. Berbeda dengan anak laki-laki, di dalam pengakuan Samin, anak laki-laki adalah anak yang mempunyai wewenang menurunkan pesan-pesan dari leluhurnya, yang bisa meneruskan ajaran Ki Samin Surosentiko. Dalam silsilah suatu keluarga, mereka sangat kuat pemahamanya, bahkan kalau turun dari sang guru sangat diperhatikan pesan-pesanya, karena masih trah langsung (keturunan satu darah).

Perkawinan dengan sesama pengikut ajaran Ki Samin mempunyai tujuan mulia karena mereka menganggap bahwa pernikahan sebagai langkah strategis, agar kelak kedua generasi baru yang akan lahir siap meneruskan ajaran para leluhurnya. Proses pencarian jodoh memang di persiapkan sedemikian rupa agar anak-anaknya mengikuti pesan para leluhurnya. Antisipasi ini dilakukan dengan cara agar mereka berada dalam satu komunitas dan lingkungan yang homogen. Di samping itu, diharapkan mereka mampu menangkal dan menepis pengaruh baru yang datang dari luar, baik pengaruh akibat perkembangan teknologi maupun pengaruh dari lingkungan yang dirasakan mulai sedikit demi sedikit berubah. Hal ini dapat disebut dengan cara menjauhkan proses akulturasi (acculturation atau culture contact) dan asimilasi.

Ada upaya lain, yang dilakukan Samin yaitu selain perkawinan adalah agar menjaga komunitas tetap homogin maka masing-masing Sedulur Sikep berdomisili saling berdekatan dalam satu komplek, atau paling tidak saling berkomunikasi dalam acara-acara tertentu termasuk acara Seksenan (mengumumkan perkawinan) anaknya. Pada saat yang tidak disengaja 
bisa bertemu, maka mereka akan berdatangan dan berkumpul saling menanyakan kabar kebaikan diantara sesama sedulur Sikep walaupun tempat tinggalnya berjauhan. Ketika peneliti menyaksikan hari perkawinan sedulur Sikep di Tambak Balong Desa Sumber, ternyata yang datang bukan hanya dari sedulur Sikep Blora saja namun juga datang sedulur Sikep dari Pati dan Kudus. Turut hadir pula sedulur Sikep dari Daerah Jawa Timur yaitu Bojonegoro dan sekitarnya. Kehadiran mereka semata-mata hanya diikat oleh rasa solidaritas yang kokoh atas dasar sesama sedulur walaupun tidak ada hubungan darah. Upaya saling mengabarkan kebaikan ternyata efektif dilakukan ketika mereka bertemu dalam acara tersebut.

Siklus slametan kematian bagi sedulur Sikep berlawanan dengan upacara-upacara layatan (Jawa) pada umumnya. Mengacu pada ajaran yang dibawa oleh Ki Samin yaitu tidak melaksanakan persis tradisi adat sebagaimana yang dilakukan pada umumnya orang Jawa. Ada perbedaan yang sangat menyolok bagi orang Jawa khususnya dalam slametan kematian, karena pemahaman slametan bagi orang Samin apabila seseorang meninggal dunia (mati) itu namanya salin (ganti pakaian). Orang yang meninggal dunia menyatu kembali dengan orang yang masih hidup, dengan batasan asalkan selama hidup ini bisa rukun (gotong-royong) dengan sesama dan berperilaku baik kepada siapa pun juga, bahkan termasuk makhluk hidup selain manusia. Samin berpendirian bahwa orang yang baik dalam hidupnya mereka akan menjalani kehidupan yang enak setelah mati.

$\begin{array}{ccr}\text { Tradisi } & \text { Jawa } & \text { yang } \\ \text { menyelenggarakan } & \text { acara } & \text { upacara }\end{array}$
peringatan hari kematian seperti, slametan mitung ndino (hari ketujuh), slametan metang puluh dino (hari ke empat puluh), slametan nyatus (slametan hari ke seratus/seratus hari, mendak pisan (satu tahun), mendak pindo (dua tahun), nyewu (seribu hari), dan seterusnya. Sebagaiamana dilaksanakan oleh orang Jawa sampai sekarang masih dilakukan dengan menambah bacaan-bacaan yang bernuansa Islam, seperti bacaan tahlil dan lain-lain, namun bagi sedulur Sikep tidak dilakukan sama sekali (Int. Salim, 1 Juli 2016)

\section{B. Temuan}

Dikarenakan model pendidikan yang unik dalam mengasuh anak-anaknya. Tipe pendidikan yang dilakukan dengan mengedepankan contoh dari kedua orang tuanya. ketika orangtua menjadi panutan dari anak-anaknya tentu menjadikan dirinya sebagai guru. Menurut ajaran Samin guru itu harus bisa dicontoh ucapan 
dan tingkah lakunya. Tanpa adanya sanksi dan ancaman dalam mendidik anak, sebab hanya akan menakut-nakuti anak sementara dirinya tidak akan berubah. Keunikan lain pemahaman sekolah bagi Samin adalah semua perbuatan yang salah hanya dirinya yang akan menanggungnya, maka orang tua tidak perlu memaksa, marah apalagi mengancam jika ada anak-anaknya membantah dari ucapan orang tuanya. ketika selesai berbicara orangtua hanya mengatakan kepada anak-anaknya kabeh gumantung ono awakmu (semua terserah kamu) kalau mau berbuat baik kamu yang menerima demikian juga sebaliknya kalau berbuat yang keluar dari perilaku orangtuanya juga dirinya sendiri yang akan menunai

\section{Kesimpulan}

Orang tua (Samin) selalu menjelaskan bukan menasehati bahwa agama nenek moyangnya memuat dan mengajarkan sesuatu yang bukan hanya mengatur satu segi kehidupan saja, tetapi masuk di berbagai segi kehidupan yang bertujuan untuk memelihara kelangsungan hidup manusia. Salah satunya melalui proses perkawinan dengan ketentuan-ketentuan yang mengikatnya. Selain itu, keberkahan perkawinan diperoleh jika pasangan suami istri tidak memiliki ikatan perkawinan dengan orang lain serta tidak terdapat beban kesalahan atau dosa. Perkawinan bertujuan untuk membina ikatan lahir batin antara seorang laki-laki dan perempuan sebagai suami istri dalam kehidupan keluarga yang bahagia berdasarkan tuntunan agama yang dipeluknya.

Pendidikan keluarga (anak) bukan barang murah dan dijual bebas, pendidikan adalah proses dari yang atas kepada yang bawah dari guru ke murid dari orangtua ke anak.kalau pendidikan hanya ingin meluluskan siswa apa bedanya dengan lembaga kursus, yang tanpa aturan dan kurikulum. Untuk apa pemerintah memikirkan sarana dan prasarana belajar, guru, buku ajar kalau hanya seperti kursus. Berapa banyak lulusan sekolah yang hanya menerima piagam, tanpa ilmu yang dapat dipraktekan setelah selesai sekolah. Mengapa berlomba lomba ingin menjadi guru kalau tidak bisa memberi tauladan kepada murid-muridnya, hanya mengajar tanpa mendidik. Akan jadi apa bangsa ini kalau pendidikan hanya formalitas. Orangtua harus memberi ruang yang longgar kepada anak-anaknya untuk memilih,. namun orangtua tetap selalu menjelaskan kepada anak laki-lakinya bahwa "kalau mau berbuat baik hanya dirinya sendiri yang akan mendapatkannya demikian juga kalau mau memilih perbuatan yang buruk juga hanya dirinya yang akan menerima akibatnya"bukan tutur, sembur, wur nanging Nyontoni luwih 
kuwat katimbang nutur (bukan Petunjuk, Nasehat) tetapi lebih hebat suritauladan).

Negara maju sangat mementingkan pendidikan tradisional, menghargai kebudayaan dan kerja keras.. fakta menunjukan bahwa apa yang telah dilakukan oleh para pakar pendidikan hanya teori, dan konsep, hanya mengutip pendapat orang lain. Pada praktiknya orang yang pandai berpidato dimimbar, orasi ilmiah dipanggung dan sebagainya sayangnya masyarakat tidak mendapatkan apa-apa,akibat dari para orator yang tidak melakukan sendiri (omdong). Keunggulan orang Samin selain apa yang disebutkan diatas adalah mendengar dan melihat,.

Jujur itu bekerja keras oleh orangtua Samin dilakukannya tanpa henti-henti, dicontohkan didepan anak-anaknya, bukan tutur,sembur (ceramah, nasehat) namun perilaku dan tindakan nyata. Anak-anak yang setiap harinya melihat film hidup dari orangtuanya tentu terpengaruh dan mengikuti bahkan mengalir dengan sendirinya. Orang yang jujur pasti menjadi pekerja keras. Tanpa pengawasan tanpa reword dari atasan, tetap dan terus dilakukan karena mereka di dorong oleh sikap jujur yang ada dalam dirinya sendiri. Jujur dapat mendatangkan energi yang luar biasa, betapa beratnya pekerjaan, susahnya usaha dan sulitnya mengolah, mengelola, memelihara tanaman dibawah terik matahari, dibawah guyuran hujan kilat dan petir, angin ribut dan dingin, gelapnya kabut, para orangtua (Samin) terus maju menerjang melangkahkan kaki kedepan tanpa pengawasanpun tetap semangat karena dalam dirinya ada kejujuran.

\section{DAFTAR PUSTAKA}

al-Akk, Syekh Khalid bin Abdurrahman. Cara Islam Mendidik Anak, Yogyakarta: Ar-Ruzz Media, 2006.

Alamsyah, Prolog Perlawanan Samin, Yogyakarta: Idea Press, 2012.

Alang, M. Sattu, Anak Saleh: Kontribusi Nilai-Nilai Sosio-Kultural Masyarakat Luwu bagi Penshalehan Anak di Pesantren Modern Datok Sulaiman Polopo, Makasar: Yayasan al-Ahkam, 2001.

Alfian, Teuku Ibrahim, Metodologi Sejarah dari Babat dan Hikayat sampai Sejarah Kritis, Yogyakarta: Gajah Mada University Press, 1984.

Ansarian, Husan, Membangun Keluarga yang dicintai Allah, Jakarta: Pustaka Zahra, 2002.

Anwar, Hasan, Pola Pengasuhan Masyarakat Adat Samin Bojonegoro, Yogyakarta: Prisma, 1985.

Arikunto, Suharsimi, Prosedur Penelitian: Suatu Pendekatan, Jakarta: Rineka Cipta, 1993.

Assegaf, Abd. Rachman, Internalisasi Pendidikan, Yogyakarta: Gama Media, 2003.

Azizah, Siti Nur. "Tinjauan Hukum Islam 
terhadap Adat Kewarisan Masyarakat Samin di Desa Sambongrejo, Kecamatan Sambong, Blora". Ilmu Syari'ah Jurusan Ahwal Al-Syakhsiyah, Semarang: IAIN Walisongo, 2009.

Bakti, Hati. Pergeseran Bahasa Jawa Pada Masyarakat Samin di Kabupaten Blora, Yogyakarta: Universitas Gadjah Mada, 2012.

Bourdieu, Pierre, Distinction. A Social Critique of the Judgement of Taste, terj. Richard Nice, Cambrige: Harvard Universiry Press, 2002.

Bourdieu, Pierre, Language and Symbolic Power, terj. Gino Raymond dan Matthew Adamson, Cambridge UK: Polity Press, 1991.

Bourdieu, Pierre, Outline of A Theory of Practice, terj. Richard Nice. Cambrige: Harvard Universiry Press, 2010.

-, Practical Reason, Stanford, Calif: Standford University Press, 1998.

Castles, Benda dan Lance. "The Samin Movement". Bijdragen tot de Taal-, Land- en Volkenkunde, Deel 125, 2de Afl, pp. 207-216, 218-240, 1969.

Chamzawi, Ahmad umar. Perubahan Identitas dan Perilaku Sosial Masyarakat Samin, Malang: Universitas Islam Negeri Maulana Malik Ibrahim, 2009.

Danandjaja, James, Kebudayaan Petani Desa Trunyan Bali, Jakarta: Pustaka Jaya, t.t.

Daradjat, Zakiyah, Metodik Kusus Pendidikan Agama Islam, Jakarta: Bina Aksara, 1995.

al-Darimi. Sunah al-Darimi, Juz 11, Jakarta: Maktabah Dahlan, 1984.
Fadholin, "Persepsi Masyarakat Samin Terhadap Lembaga Pendidikan Islam di SMU NU Kradenan Blora", Tesis, UIN Sunan Kalijaga Yogyakarta, 2012.

Fauzi, M. Zainuddin Lutfi, "Makna Pemilu Presiden 2009 bagi Masyarakat samin, Desa Sambongrejo Kecamatan Sambong Kabupaten Blora", Tesis, Program Magister Sosiologi Fakultas Ilmu Sosial dan Ilmu Politik. Universotas Airlangga. Surabaya, 2013.

Foucault, M. Discipline and Punish: The Birth of a Prison, London: Penguin, 1991.

Fuadudin, T.M., Pola Pengasuhan Anak dalam Keluarga Islam, Jakarta: Lembaga Kajian Agama dan Jender, 1999.

Gaventa, J., Power after Lukes: a Review of the Literature, Brighton: Institute of Development Studies, 2003.

Goodman, J. Douglas dan George Rister, Modern Sociological Theory, terj. Astry Fajria, Teori Sosiologi Modern, Jakarta: Kencana, 2004.

Greertz, Clifford, Abangan, Santri, Priyayi dalam Masyarakat Jawa, Jakarta: PT Dunia Pustaka Jaya, 1981.

Hamidi, Metode Penelitian Kualitatif, Malang: Universitas Muhammadiyah Malang Press, 2004.

Hamim, Nur, Kesehatan Mental Islami, Telaah atas Pemikiran Hamka, Yogyakarta: IAIN Sunan Kalijaga Press, 1977.

Hanks, William F. "Pierre Bourdieu and 
the Practices of Language”. Annual Review of Anthropology, Vol. 34, pp. 67-83, 2005.

Harahap, Nasaruddin, Dakwah dalam Pengembangan Masyarakat, Yogyakarta: Pustaka Pesantren, 2011.

Haryatmoko, "Habitus dan Kapital dalam Strategi Kekuasaan. Teori Habitus Strukturasi Pierre Bourdieu dengan Orientasi Budaya", makalah dipresentasikan di Pasca-Sarjana Sosiologi Universitas Indonesia. 26 Agustus 2010.

Hutomo, Sadi Suripan, "Bahasa dan Sastra Lisan Orang Samin Daerah Kabupaten Blora", Basis, No. XXXII, Yogyakarta: Andi Offset, 1983.

-------, Tradisi dari Blora, Semarang: Citra Almamater, 1996.

Ilbana, "Masyarakat Samin di Bojonegoro, Studi Antropologi Agama", Tesis, UIN Sunan Kalijaga Yogyakarta: 2005.

Ismail, Nawari, Relasi Kuasa dalam Pengubahan Budaya Komunitas Negara, Muslim, Wong Sikep, Bandung: Karya Putra Darwati, 2012.

Jam'an, Nur, Fikih Munakahat, Semarang: Dimas, 1993.

Jamil Abdul dkk., Islam dan Kebudayaan Jawa, Yogyakarta: Gama Media, 2000.

Jannah, Siti Raudhatul, "Akulturasi Budaya Ajaran Samin Surasentika dan Islam di Desa Blimbing Kecamatan Sambong Kabupaten Blora". Skripsi Fakultas Ushulludin UIN Sunan Kalijaga, 2009.
Karman M., Sapiana, Materi Pendidikan Agama Islam, Bandung: Remaja Rosdakarya, 2001.

Karsten, Matthew R. Jones and Helena, Giddens's Structuration Theory and Information Systems Research, MIS Quarterly. Vol. 32, No. 1, pp. 127-157, 2008.

Kartanegara, Mulyadi, Menembus Batas Waktu, Bandung: Mizan, 2002.

Khaldun, Ibn, Muqaddimah, terj. Budi Hardiman, Yogyakarta: Kanisius, 1994.

King, Viktor, "Some Observations on the Samin Movement on North-Central Java: Suggestions for the Theoritical Analysis of the Dynamics of Rural Unrest", Bijdragen tot de Taal-, Land- en Volkenkunde, Deel 129, 4de Afl, pp. 457-481, 1973.

Kirom, Syahrul, Ajaran Moral Masyarakat $\underline{\text { Samin Dalam Perspektif Etika: }}$ Relevansinya Bagi Pengembangan Karakter Bangsa, Yogyakarta: Universitas Gadjah Mada Press, 2012.

Korver , A. Pieter E, "The Samin Movement dan Millenarism". Bijdragen tot de Taal-, Land- en Volkenkunde, Deel 132, 2de/3de Afl, pp. 249-266, 1976.

Kosim, Nanang, Pendidikan Agama dalam Keluarga, Bandung: Fakultas Tarbiyah, UIN Sunan Gunung jati, t.t. 